\title{
Imperial Defence in the Indian Ocean, 1928-60
}

\section{Chris Madsen}

Le concept persistant de défense " impériale "-plus récemment surnommée "commonwealth"-a souligné une présence britannique viable dans l'océan Indien. La Marine royale britannique avait garanti des lignes de communication maritimes sur sa largeur et la sécurité des possessions britanniques le long de ses rives. La station ou flotte dite des Indes orientales était toujours inférieure en stature et en priorité que, par exemple, celle de la Méditerranée ou celle du Pacifique, mais a gagné en importance avec la croissance successivement de la menace et des conquêtes japonaises, des actes allemands de guerre de commerce intermittente aussi bien en surface que sous l'eau, et de l'élargissement de la portée navale mondiale de l'Union soviétique. Le triangle de l'Inde, de l'Afrique du Sud et de l'Australie était à la base de l'encouragement britannique pour la constitution de marines permanentes et aux vues similaires, capables de travailler de manière coopérative avec les forces navales britanniques disponibles. Ce document met l'accent sur les dimensions financières de ces accommodations, la politique nationale d'association, et l'idée d'une flotte commune financée dans une moindre mesure par chaque pays concerné. Pendant trop longtemps, la Grande-Bretagne a pris pour acquis autant l'océan Indien que ses partenaires.

Great Britain, as an imperial power, exercised a privileged position in the Indian Ocean by virtue of naval and military strength. The jewel India was seized from foreign rivals and local rulers, whilst territories and colonies acquired, settled, and exploited ringed its shores from Africa in the west to the federated Malaya states and Australia in the east. ${ }^{1}$ At the close of the First World War, any map of this region would have shown great blotches of red identifying lands and islands affiliated with the British Empire. The Indian Ocean provided key sea lines of communication for trade routes and strategic movement between the Far East and Europe, especially through the Red Sea and

1 Gerald S. Graham, Great Britain in the Indian Ocean (Oxford: Clarendon Press, 1967). Stephen Taylor, Storm and Conquest: The Battle for the Indian Ocean 1808-1810 (London: Faber, 2007). Admiral Herbert Richmond, The Navy in India, 1763-1783 (London: E. Benn, 1931).

The Northern Mariner/Le marin du nord XXIV, Nos. 3 \& 4 (Jul. \& Oct. 2014), 135-156 Canadian Military History 23, Nos. 3 \& 4 (Summer \& Autumn 2014), 135-156 
British-controlled Suez Canal into the Mediterranean. ${ }^{2}$ Imported commodities from this region - petroleum, metals, rubber, and tea - were staples to Great Britain's modern economy and society. In spite of the Indian Ocean's obvious importance, naval forces kept on the East Indies station during peacetime were modest compared to other British areas of interest, a pattern continued by necessity into wartime. Dedicated bases and facilities remained under-developed, whereas the Admiralty looked to the main constituent entities to assume some greater burden of self-defence in the maritime sphere and contribute to notional arrangements for Commonwealth naval cooperation. ${ }^{3}$ Reconciling the defence requirements and challenges of a mature empire, comprised of disparate parts exercising various degrees of autonomy in transition to a Commonwealth of nations, at times proved as difficult a proposition as meeting real and perceived external threats to Great Britain's imperial position in the Indian Ocean.

The rationale for imperial defence, later subsumed under the moniker 'Commonwealth defence', was predicated on continued British presence and leadership in the Indian Ocean. Over just three decades, the Royal Navy went from virtual master of this large sea expanse to inglorious retreat due to constrained resources and a changing world. $^{4}$ The outcome was perhaps inevitable, though not always foreseeable. The triangle of South Africa, India and Australia appeared a solid basis for holding onto British interests in the Indian Ocean, if they remained interested and loyal to the Commonwealth. Attempts to encourage and cultivate the development of navies in those countries patterned on the Royal Navy and available for collective purposes addressed the basic problem and shortfalls in imperial defence: too much far-flung territory and too few ships. Indigenous naval forces, at first anticipated coastal defence tasks supplemental to the Royal Navy's primary role in security of sea communications, grew dramatically under wartime conditions into varied and demanding roles in support of naval and military operations against a common enemy. They eventually aspired to national navies suited to the political and financial circumstances of the respective countries involved and their relationship with Great Britain and the Commonwealth. In each case, South Africa, India and Australia were afforded British-type equipment and warships, and naval professional expertise, as well as training opportunities. The expectation was that they would willingly accept the premises of imperial defence and subordination to the Admiralty's concept of shared Commonwealth naval responsibilities in the Indian Ocean. But this assumption proved impractical, given British weakness and the independent inclinations of older and newer Commonwealth nations soon looking toward other defence arrangements and sources of supply. The British too long took the Indian Ocean and its main partners there for granted.

2 A.G. Boycott, The Elements of Imperial Defence: A Study of the Geographical Features, Material Resources, Communications \& Organization of the British Empire (Aldershot: Gale and Polden, 1931), 325.

3 Ashley Jackson, War and Empire in Mauritius and the Indian Ocean (Houndmills, Basingstoke: Palgrave, 2001), 39.

$4 \quad$ Greg Kennedy, “The Royal Navy and Imperial defence, 1919-1956,” in Greg Kennedy (ed.), Imperial Defence: The old world order 1856-1956 (London and New York: Routledge, 2008), 134. 


\section{Sloops and Cruisers: Starting-Point for Small Navies in the 1930s}

The promotion of naval forces in the dominions and India was hardly a new idea. The Admiralty had entertained building and maintenance of distributed naval units amongst the empire in lieu of direct cash contributions for British naval squadrons since at least 1911. During the First World War, ships and transports from India and Australia had been placed under British operational control in the Indian Ocean, and in any future major conflict were expected to do the same. The Admiralty's preference for a proposed unified imperial navy encompassing all parts of the British Empire according to ability to pay met a decidedly lukewarm response from dominion political leaders. Recommendations from Admiral Lord Jellicoe's extensive tour of India, Australia, New Zealand and Canada in 1919 for improvement of naval preparedness and local defences in the end largely went nowhere. ${ }^{5}$ Fundamental differences over naval policy, financial commitments, and appropriate means of contribution to imperial defence remained outstanding between the British and the others. The 1922 Washington Naval Treaty further complicated relations, since the types and tonnage of some warships were restricted and 'building holidays' imposed. The dominions eagerly took peace dividends by reducing armed forces.

The language of compromise used on the topic of naval defence at imperial conferences in 1923 and 1926 left much to interpretation. The Admiralty believed that certain dominions had committed to a four-phase expansion of naval forces for work with the Royal Navy, wherein the dominions and India merely conceded that sufficient attention should be given to provision of naval bases for fuelling and repair, coastal defence, and security of sea communications in adjacent waters. Most significantly, the level of involvement was left to individual governments to decide. ${ }^{6}$ Any naval forces raised by South Africa, India and Australia for deployment in the Indian Ocean in the first instance belonged to them and given over to British command and control only voluntarily. In these years of peace, the whole matter was rather abstract, because actual naval forces were either incredibly small or non-existent, representing more an aspiration. Nonetheless, the Admiralty pushed for more formal arrangements and extended assistance in personnel, training, and equipment where possible, in the hope of fostering greater cooperation and interoperability. British efforts in this direction, while slow in progress and subject to numerous setbacks, actually gained some forward momentum after 1928.

The continental island of Australia sitting astride the Indian and Pacific Oceans appeared, at least outwardly, appreciative of sea power and its role in imperial defence. The Commonwealth of Australia had been the most accommodating in accepting the Admiralty's concept of a common navy. ${ }^{7}$ A British flag officer sat on the naval board and

5 United Kingdom National Archives (UKNA), ADM 1/8548/2, "Imperial Naval Co-operation: History of Lord Jellicoe's Naval Mission to India and the Dominions in H.M.S. New Zealand, 1919-1920."

6 Nicholas Tracy (ed.), The Collective Naval Defence of the Empire, 1900-1940 (London: Ashgate for the Navy Records Society, 1997), 421.

7 John McCarthy, Australia and Imperial Defence 1918-39: A Study in Air and Sea Power (St. 
headed the Royal Australian Navy, which comprised a handful of cruisers, destroyers, and submarines transferred from the British as well as an Australian-built seaplane carrier. For purposes of discipline, Australian officers were interchangeable with British and all Australian naval personnel fell under British statute. Budgetary pressures, however, forced major reductions in establishments and the inspector-general of the Australian military forces advocated getting rid of the navy altogether by reverting back to a less costly monetary contribution to the Admiralty for naval defence. ${ }^{8}$ Although the Australian navy institutionally survived deep retrenchment and reductions, what little investment could be made favoured naval bases and forces on the east side of Australia centred around Sydney rather than such places as Fremantle near Perth on the west side facing the Indian Ocean. Since Japan was the most likely enemy in strategy and planning, most attention was given to naval operations and possible invasion from the northeast. ${ }^{9}$ It was presumed that Australian warships would reinforce the Royal Navy on the China station to contain Japanese ambitions, in effect a form of forward defence away from Australian shores.

The Indian sub-continent was better situated geographically, but the Royal Indian Marine was still technically a non-combatant force - a mere supporting transport arm for the Indian army. British India was a land power with a large military garrison for protection of the northwest frontier, maintenance of internal security, and up-holding of imperial interests throughout the surrounding region. ${ }^{10}$ A scheme for the Royal Indian Marine's reorganization put forward by commander-in-chief East Indies, Rear-Admiral Herbert Richmond, received conditional endorsement from a departmental committee presided over by General Lord Rawlinson, commander-in-chief in India (with Richmond sitting as a member). ${ }^{11}$ A British flag officer was to be appointed, reporting to the Indian government, and an armed force of four sloops, two patrol boats, and four trawlers constituted. The Indian legislative assembly, however, rejected by one vote the navy bill necessary to bring the proposed scheme into effect, on the grounds that Indians already bore the heavy cost of imperial defence and too few opportunities were provided to entry of non-white candidates for commissions. ${ }^{12}$ Anglo-Indians officered India's maritime forces, while non-white other ranks were recruited predominantly from the sub-

Lucia: University of Queensland Press, 1976), 16.

8 UKNA, ADM 1/8743/109, "Report for the Inspector General of the Australian Military Forces by General Sir H.G. Chauvel, G.C.M.G., K.C.B.," 15 April 1930.

9 David C. Evans and Mark R. Peattie, Kaigun: Strategy, Tactics and Technology in the Imperial Japanese Navy 1887-1941 (Annapolis: Naval Institute Press, 1997), 450.

10 Thomas R. Metcalf, Imperial Connections: India in the Indian Ocean Arena, 1860-1920 (Berkeley: University of California Press, 2007), 68. Tim Moreman, The Army in India and the Development of Frontier Warfare 1847-1947 (London: Macmillan, 1998). Pradeep Barua, "Strategies and Doctrines of Imperial Defence: Britain and India, 1919-45," in Journal of Imperial and Commonwealth History 25 (1997), 242.

11 UKNA, ADM 116/2473, "Report of the Departmental Committee appointed to prepare a scheme for the reorganisation of the Royal Indian Marine," 1925. Captain Edward Headlam, “The Royal Indian Navy," in Naval Review 15 (1927), 841. 
continent's coastal regions and later the Punjab. Soon after, the Admiralty sent out a rearadmiral, Humphrey Walwyn, to organize the headquarters, base and dockyard at Bombay, and institute squadron training for available ships pending reintroduced legislation that formally created the Royal Indian Navy in $1934 .{ }^{13}$ Relaxation of restrictions on service of qualified Indians in officer ranks was a small concession. The Royal Indian Navy's budget was capped as a line item in India's total military expenditures, in addition to an annual $£ 100,000$ paid by the Indian government to Great Britain for naval defence, which the British were careful to take into calculations. Such subsidies made the East Indies fleet based on nearby Ceylon, no more than five or six older warships at any one time (of which India paid for three), more or less viable. ${ }^{14}$ For most observers, the Royal Navy was still the primary guarantor of India's security from the sea.

The development of naval forces in South Africa exhibited some of the same pressures and inclinations, but took a decidedly different turn. The Union of South Africa, like India, was traditionally a land power with a history of independence and military prowess (before and after British subjugation). A white minority, which filled most key positions in government, business, and the military, ruled over a broader black population. South Africa's geographical position at the continent's southern end controlled passage from the Indian Ocean into the South Atlantic, and the coastline boasted several natural harbours and developed ports. Yet, available maritime forces were minuscule: the South African Naval Service consisted of a pair of minesweeping trawlers for sea training purposes and a loaned surveying vessel engaged in hydrographical work. The South African government at least seemed interested in numerous Admiralty suggestions and proposals for up-grading the naval service with the addition of trained personnel and more capable warships, though the naval officer commanding, Commander Robert FitzGerald lent from the Royal Navy, reported chronic under-funding. South Africa paid for completion of expanded capital works at the Simon's Town dockyard and construction of large fuel storage tanks for naval use as a stimulus to local economies; continually pared down naval estimates, however, were hard to justify in a country disposed toward expanding land and air forces first, for internal security as much as external threat. South Africa's prime minister and defence minister sounded out the Admiralty about abolishing the naval service entirely and going back to direct cash contribution for maintaining Royal Navy warships on the Africa station, a price fixed at the cost of at least two cruisers. ${ }^{15}$ Even this sum was deemed too much, and the South African Naval Service simply languished, unable to attract quality personnel with the paltry pay scales offered. The boys training ship General Botha at Simon's Town essentially became a feeder for the Royal Navy, preparatory for commercial employment, or in the last instance a career in the South African naval forces. In late 1934, the South African government paid off and returned the two

13 UKNA, ADM 1/8737/96, Report Rear-Admiral Humphrey Walwyn to Secretary Admiralty, 7 June 1929.

14 UKNA, ADM 116/2915, Precis, 16 June 1932. UKNA, ADM 1/9767, Memorandum, CinC East Indies station to Secretary Admiralty, "Command and Employment of Eastern Forces," 3 November 1938. 
minesweeping trawlers to the Royal Navy without replacement.

In spite of the constant imperative of demonstrating the budgetary and institutional relevance of small maritime forces within larger defence organizations dominated by land forces, the navies of Australia, India and South Africa evolved along unique paths and circumstances suited in some measure to the broader needs of imperial defence in the Indian Ocean. India, like Australia and South Africa previously, ended payment of its annual subvention and assumed full responsibility for coastal defence. Landward, the army manned coastal artillery and fixed fortifications, mostly around ports and strategic spots along shorelines; seaward defence involved the execution of minesweeping, auxiliary patrol, port defence, and naval control of shipping in time of war or heightened international tension. These duties required mostly smaller naval vessels such as auxiliaries, motor launches, and monitors not meant to go too far afield. Though the Admiralty provided some equipment and arms, defensive measures in ports and existing naval bases fell to the countries involved and consequently varied widely. The dominions were also asked to contribute financially to the expense of renewed construction of the main naval base and dockyard at Singapore, held out to become the impenetrable bastion of British power in the Far East once complete, thereby buying into the speculative argument that the safety and security of the Indian Ocean somehow relied upon it. ${ }^{16}$ Whether the money might have been better spent developing and improving several bases at strategic points, such as Western Australia, Ceylon and Aden, was a question hardly broached at the time. Sydney was later chosen over Fremantle. ${ }^{17}$ Certainly, the Admiralty encouraged the dominions and India to take on coastal defence duties in local waters, if for no other reason than to leverage the Royal Navy's focus on protection of trade and sea lines of communication in the Indian Ocean.

The acquisition of warship types and planned employment in the three navies, either alone or in conjunction with the Royal Navy, promoted economy, efficiency and uniformity. The larger warships intended to operate from bases necessarily had to have endurance to cover large distances, good sea-keeping characteristics, speed sacrificing some armour protection, and suitability to working in tropical and sub-tropical climates. The obvious choice was the cruiser, of which Australia had the venerable Adelaide of 1922 vintage, two Scottish-built Kent-class (otherwise known as County-class) heavy cruisers, and three newer Leander-class light cruisers completed in $1934 .{ }^{18}$ The Indian government also wanted to obtain a cruiser, but was persuaded by the Admiralty to take ocean-going sloops instead because the 1930 London Naval Treaty put limits on the number and size of cruisers available to Great Britain and the British Empire. ${ }^{19}$ The largest sloops - a poor man's cruiser - were capable escorts, easier to maintain, and could be built without restriction as a type of ship outside naval limitation. Unlike additional cruisers, any sloops operated by the dominions and India were not subtracted from

16 UKNA, ADM 1/9126, Notes First Lord answer to parliamentary question, 9 July 1930.

17 UKNA, ADM 1/11172, Staff Minute Director of Plans, 7 April 1941.

18 UKNA, ADM 1/9427, Memorandum “Cruiser Policy," 11 May 1937.

19 British Library, India Office papers, L/MIL/5/958, Notes of talk between Colonel Beazley, J.S. Barnes and Captain Phillips at Admiralty, 1 March 1932. 
corresponding British numbers, a dominant consideration prior to final demise of the naval limitation system in 1936. The Royal Indian Navy had two sloops built in British shipyards, Hindustan and Indus, and the Royal Australian Navy began construction at Cockatoo island dockyard (Sydney) of its own variants of the British Grimsby design. The Admiralty dangled offers of sloops and cruisers to South Africa at discounted prices as well, but short of giving them away free-of-charge, the government in Pretoria stayed non-committal. New modern warships were preferred to older second-hand cast-offs of doubtful operational value and expensive to maintain.

Despite tough economic times of depression, Australia and India found money to buy and operate the latest designs of ships suited to their own budgets and needs. Australia exercised a squadron as part of deployed Royal Navy forces in the Far East. ${ }^{20}$ South Africa was at the opposite end of the spectrum, having abdicated naval pretensions for the time being. In the case of India, actual contact between the Royal Indian Navy and the East Indies station was limited to occasional visits. The new warships performing coastal defence and occasional escort duties in the Indian Ocean furnished suitable platforms for broadening skills and experience among personnel entering into the small navies.

The technical demands of running cruisers, sloops, and other naval vessels necessitated some emphasis on recruitment, training, and provision of adequate reserves. Cadres of permanent long-service personnel were the backbone of the little fleets, notwithstanding small numbers and corresponding limited career and promotion prospects. Job security partly made up for poor pay and hard sea time. The Royal Australian Navy experienced trouble filling its ranks, and relied to greater extent on secondments and loaned personnel from the Royal Navy. ${ }^{21}$ The Australian naval reserve, in a state of gradual decline since the start of the decade due to government cost-cutting, dwindled to low levels until belated efforts at rearmament. Good candidates gravitated to the army and air force because life in naval service was considered full of hardship and long periods of time spent away from Australia, given the navy's imperial focus. For much the same reason, the Royal Indian Navy tried as much as possible not to compete with the Indian army for sources of personnel: long-service officers and sailors were drawn from seafaring occupations in India; a nascent naval volunteer reserve targeted merchant and commercial classes after 1938; and the door opened slightly wider for selection of educated Indians. ${ }^{22}$ Marine engineers and technical specialists, crucial to any modern naval force, were in highest demand. Unlike the professional Indian army, the small Royal Indian Navy was almost devoid of higher command opportunities because seconded senior and middle rank British officers filled those few positions that existed. In South Africa, the existing Royal Naval Volunteer Reserve (South Africa Division)

20 John McCarthy, "Planning for Future War 1919-1941: The Armed Services and the Imperial Connection," in Revue Internationale d'Histoire Militaire 72 (1990), 119.

21 Jason Sears, “1929-1939: Depression and Rearmament,” in David Stevens (ed.), The Royal Australian Navy (Melbourne: Oxford University Press, 2001), 75.

22 UKNA, ADM 116/3800, Memorandum "Formation of Indian Naval Reserves," 27 January 1938. NMM, RIN/3/2, "The Royal Indian Navy, Its Vicissitudes, Administration and Development" 1939. 
preserved the nucleus of a semi-trained naval force minus armed ships. As volunteers signed up for four years of training and at least fourteen days of continuous sea training, numbers fluctuated, though never higher than sixty-five officers and a thousand other ranks. ${ }^{23}$ Due to racial restrictions, personnel recruited into South Africa's naval reserve were predominantly white. For the South African government, the small investment was the minimum to run naval shore establishments and ensure basic sea skills; the personnel so enrolled lived an existence apart from the rest of the South African military since it was understood that naval volunteer reservists were earmarked for general service in the Royal Navy should hostilities commence. ${ }^{24}$ Admittedly uneven, the arrangements for naval preparedness and imperial defence in case of need favourably positioned the three respective naval forces for the coming world war against the Axis powers of Nazi Germany, Fascist Italy, and Imperial Japan.

\section{Global War reaches the Indian Ocean}

In terms of pre-war planning, the Indian Ocean seemed a relatively safe theatre of operations distant from rising tensions in Europe and even the growing militaristic ambitions of Japan in China and the Pacific. Italy's military conquest of Abyssinia for the first time brought closer the prospect of bases and fleet units in the hands of an unfriendly power with access to the Red Sea and the wider Indian Ocean. ${ }^{25}$ Italy's geographical position in the Mediterranean and suspected plans for territorial expansion into North Africa directly threatened British movement through the strategic Suez canal, which at worst could be strangled from both ends. As a contingency, additional fuelling stations and store depots were established in the Indian Ocean for passage of a prospective British fleet to reinforce Singapore, around the Cape of Good Hope if necessary. ${ }^{26}$ The aged Royal Navy cruisers kept on the East Indies station were too vulnerable and singly no match for the guns of enemy pocket battleships. After the outbreak of war, the German surface raiders Graf Spee and Admiral Scheer ranged into the Indian Ocean to sink merchant ships and rendezvous with pre-positioned supply ships. ${ }^{27}$ Auxiliary merchant cruisers and U-boats soon followed. The Australian light cruiser Sydney was lost with all hands in a firefight with the disguised German auxiliary

23 UKNA, ADM 1/20842, "Notes on the Formation and Development of the South African Naval Forces."

24 André Wessels, "The first two years of war: The development of the Union Defence Forces (UDF), September 1939 to September 1941," in The South African Military History Journal, 11/5 (2000); on-line at http://samilitaryhistory.org/vol115aw.html, accessed 20 January 2011. UKNA, ADM 1/9914, CinC East Indies to Secretary of Admiralty, "Report on the Emergency," 23 November 1938.

26 Andrew Field, Royal Naval Strategy in the Far East, 1919-1939: Preparing for War Against Japan (London: Frank Cass, 2004), 107.

27 L.C.F. Turner, H.R. Gordon-Cumming and J.E. Betzler, War in the Southern Oceans, 193945 (Cape Town: Oxford University Press, 1961). 
Kormoron on the ocean's eastern edge. ${ }^{28}$ Convoying of troops from New Zealand, Australia, India and South Africa to war theatres in the Middle East and North Africa, however, proceeded unmolested. The principles of imperial defence appeared to be working in practice. Australian, Indian and South African ships transferred to Admiralty control were immediately sent to the Red Sea and the Mediterranean to offset British naval losses. Adolf Hitler and the German high command, enthralled with invasion of the Soviet Union, chose not to follow-up on victories in the Balkans, the Luftwaffe's mass airborne descent on the island of Crete, and the advances of Erwin Rommel's Afrika Korps, which might have threatened the main naval base at Alexandria and Great Britain's whole position in Egypt, thereby unhinging the door into the Indian Ocean.

Instead, the main danger came from Japan's surprise attack on the US fleet at Hawaii and rapid offensive operations against American, British and Dutch territories in the Far East. Japanese land-based aircraft sank the ill-fated Prince of Wales and Repulse, the fortified Singapore base and its garrison surrendered, and remaining allied naval forces made a last stand trying to hinder the invasion of Java. ${ }^{29}$ From a strategic and imperial defence perspective, little was left to stop Japanese ambitions and offensive power. To highlight this fact, aircraft from Vice-Admiral Chūichí Nagumo's First Air Fleet, comprising the very carriers that had wreaked havoc at Pearl Harbor, attacked Australia's northern port of Darwin with impunity. ${ }^{30}$ Though the operation turned out to be a raid rather than precursor to further invasion southward, the Japanese were determined to deal quickly with the British in turn before the Americans could intervene. In April 1942, Nagumo and his carrier task force sailed westward to seek out and destroy the British eastern fleet, in addition to covering the movement of Japanese troops by sea into Burma through the port of Rangoon. ${ }^{31}$ The Indian Ocean became a front-line theatre in the naval war.

The intended Japanese attempt to draw the British into a fleet action was the first and last time two major wartime fleets sparred in the Indian Ocean, with far-reaching effects on subsequent dispositions. A Canadian Catalina reconnaissance plane flying from Ceylon spotted Nagumo's task force, giving some forewarning of a massed aerial attack on the harbour at Colombo and alerting Admiral James Somerville of the extreme danger to his concentrated naval forces at Addu Atoll, an undeveloped secret anchorage in the Maldives islands chain. ${ }^{32}$ The British aircraft carriers were outnumbered by the

28 Peter Hore, Sydney - Cipher and Search: Solving the last great naval mystery of the Second World War (Seafarer, 2009).

29 S.W. Roskill, The War at Sea vols. 1-2 (London: HMSO, 1956).

30 David A. Thomas, Japan's War at Sea: Pearl Harbor to the Coral Sea (London: André Deutsch, 1978), 54-66.

31 Paul S. Dull, A Battle History of the Imperial Japanese Navy (1941-1945) (Annapolis: Naval Institute Press, 1978), 104.

32 UKNA, ADM 199/623, Report CinC East Indies to Admiralty "Report of Air Attack on Colombo," 20 April 1942. UKNA, 23/4801, Report Air Staff CinC Ceylon "Japanese Air Attack on Colombo on the 5th April, 1942," 9 June 1942. The Canadian plane piloted by Squadron Leader Leonard Birchall of 413 RCAF Squadron flying from Ceylon was shot down by Nagumo's fighter screen. 
better-trained and experienced Japanese, while a squadron of unmodified older ' $R$ '-class battleships lacked speed and protection to become more than just sitting targets. In a very one-sided engagement, Japanese carrier aircraft sank the cruisers Dorsetshire and Cornwall, caught in the open trying to reach the main force. ${ }^{33}$ After attacking the British naval base at Trincomalee, Nagumo's planes located and sank the small aircraft carrier Hermes (fresh from repair and refit at Simon's Town, South Africa) and its consort the Australian destroyer Vampire. Somerville decided a fleet-in-being was the most sensible course and retired with the whole British eastern fleet to Mombasa, Kenya on the west side of the Indian Ocean. ${ }^{34}$ Nearby Kilindini, with its large natural harbour, was developed into a headquarters and main base, Trincomalee then considered too-exposed. Certainly not lost on General Archibald Wavell, commander-in-chief in India, the Royal Indian Navy was the only organized naval force left to face an anticipated sea-borne Japanese invasion of Ceylon and the Indian sub-continent. The sloop Indus had been bombed and sunk at Akyab Island during the British military retreat. ${ }^{35}$ Fortunately, a separate Japanese naval force was content to sweep the Bay of Bengal of shipping as Nagumo turned home for Japan with the notches of an aircraft carrier and 'third-time lucky' harbour raids to his credit. Subsequent destruction of the Japanese fast carrier task force in the Battle of Midway against the Americans effectively removed another offensive operation of the same scale, though the British still worried that superior Japanese fleet units supported by land-based aircraft might sally into the Indian Ocean at any time. ${ }^{36}$ Burma, lost to the Japanese, provided them a springboard for land and air operations into the area of Assam on India's eastern frontier. Embodying both the strength and weakness of imperial defence, the Royal Navy sought the safety of secure bases far away from the enemy by restricting offensive action. The situation determined the destiny of navies in Australia, India and South Africa.

The reversal of British fortunes in the Indian Ocean occasioned dramatic rethinking and expansion of naval forces in the two dominions and India. Absent the Royal Navy, Australia turned to the Americans for assistance. General Douglas MacArthur, as the designated supreme commander Southwest Pacific with a headquarters in Brisbane, integrated the Australian armed forces into American plans and the Royal Australian Navy, still headed by a British flag officer, came under the operational control of an American admiral. ${ }^{37}$ Though the weight of naval and military effort was inevitably north toward New Guinea, a number of Australian sloops and destroyers were still attached to the British eastern fleet in the Indian Ocean. The Australians built frigates, corvettes, and fleet minesweepers as well, but experienced difficulties manning them

33 UKNA, ADM 1/12269, Admiral James Somerville "Report of Sinking of H.M. Ships Dorsetshire and Cornwall," 12 April 1942

35 UKNA, ADM 1/19831, Letter Government of India to India Office "Loss of H.M.I.S. Indus," 25 September 1946.

36 Jeremy Black, "Midway and the Indian Ocean," in Naval War College Review 62/4 (2009), 137.

37 Gavin Long, MacArthur as Military Commander (London: B.T. Batsford, 1969), 94. 
despite a threefold increase in personnel. The Royal Indian Navy, as India developed into a major base of operations, underwent tremendous growth in shore establishments, training facilities, and number of ships. By October 1943, personnel totalled 2,000 officers and 22,000 other ranks. Vice-Admiral John Godfrey, the erstwhile director of naval intelligence at the Admiralty, became flag officer commanding the Royal Indian Navy. ${ }^{38}$ From a headquarters in New Delhi, a naval staff rationalized and consolidated the much enlarged naval force. ${ }^{39}$ The Indian government procured modified Black Swanand Bittern-class sloops from British sources and constructed simpler design minesweepers, trawlers and motor launches in India and Australia; the Royal Indian Navy also built-up credible transport and landing craft capabilities to assist the army. Since the start of the war, South Africa had operated a seaward defence force which according to the closest British admiral was "a military force carrying out naval duty... the chief motive for the formation of this force is to enable the Government to break away from control of South Africa Naval Forces by British Senior Naval Officers and to proclaim that South Africa is running her own Naval force without help of [the] British Admiralty." ${ }^{\prime 0}$ In late 1942, a newly-christened South African Naval Forces expanded into a force eventually reaching 504 officers and 4,696 other ranks (another 786 officers and 2,151 other ranks served directly in the Royal Navy). ${ }^{41}$ The majority of small ships were engaged in minesweeping and escort duties near South African waters. Later, the Admiralty also asked the South African government to man three Loch-class frigates building in Great Britain transferred gratis to Union control. ${ }^{42}$ A wartime expedient, these larger warships provided opportunity for gaining more experience acting independently and with British fleets. The British-pattern equipment and common training standards in the three navies enabled interchangeable employment on imperial defence and wartime duties.

Arguably, the most constant and important task was escort work along sea lines of communication in the Indian Ocean. With Royal Navy forces continually drawn off elsewhere, Indian, Australian and South African naval forces filled the gaps and assumed a fair share of convoy protection. The Royal Indian Navy Basset-class minesweeper Bengal took on two Japanese auxiliary raiders each ten times its size and managed to sink one by gunfire. ${ }^{43}$ Regular convoys protected by South African Naval Forces surface escorts were initially started through the Mozambique Channel from Durban to Mombasa and Aden, and later extended to Indian and Australian ports. ${ }^{44}$ Establishment of airfields

38 IWM, 74/96/1, Admiral John H. Godfrey naval memoirs. Patrick Beesly, Very Special Admiral: The Life of Admiral J.H. Godfrey, C.B. (London: Hamish Hamilton, 1980).

39 UKNA, ADM 1/16359, "Report on the Royal Indian Navy for the Year ending 1st May, 1944."

40 UKNA, ADM 1/9828, Message CinC South Atlantic to Admiralty, 21915 November 1939.

41 UKNA, ADM 1/19434, Memorandum "The South African Naval Forces," 4 December 1945.

42 UKNA, ADM 1/16184, Message Admiralty to CinC South Atlantic 22 1647A December 1944.

43 NMM, RIN Association collection, RIN/7/1, Report CO HMIS Bengal to FO Ceylon "Action with Two Enemy A.M. Cruisers on 11th November 1942," 12 November 1942.

44 UKNA, ADM 1/12590, "U-Boat Threat in the Indian Ocean," 4 September 1943. 
in South Africa, Kenya, India and Ceylon extended air coverage by RAF Coastal Command and the Fleet Air Arm. The actual effectiveness of flying boat and land-based aircraft, however, was hard to gauge because training and coordination were recognizably poor as late as $1943 .^{45}$ German and Japanese submarines, some working out of Penang, posed a significant, if somewhat sporadic, threat. ${ }^{46}$ As a consequence, escort carriers were employed on trade protection in the Indian Ocean to cover the distances that landbased aircraft could not reach. ${ }^{47}$ These standard merchant hull ships with a landing deck were built in the United States under Lend-Lease for the Royal Navy and carried both American and British-type aircraft. They worked in groups with sloops, destroyers, and frigates as screens to convoyed merchant ships. South Africa, for example, experienced some typical problems of a semi-trained escort force learning on the job. ${ }^{48}$ British reinforcement of the eastern fleet in early 1944 eased the shortage of surface escorts and furnished more fleet units for independent action in the Indian Ocean. Plans for retaking the offensive against the Japanese in southeast Asia relied on major allied contributions, particularly from the Royal Indian Navy. ${ }^{49}$ Support to military operations was another key feature of imperial defence.

The naval forces of Australia, India, and South Africa participated in several important military campaigns bordering the Indian Ocean. The British first cleared Italian East Africa in 1941, with military drives from Sudan and Kenya. The Royal Indian Navy, operating in the Red Sea, transported Indian troops to Berbera and swept approaches to the port of Massawa. ${ }^{50}$ The latter was rehabilitated and turned into a minor operating and repair base. In an operation known as 'Ironclad', a British seaborne force landed on the Vichy French island of Madagascar to seize the port Diego Saurez at its northern tip in May 1942. The expedition was mounted from Durban and included units of the South African army and air force. ${ }^{51}$ South African warships performed

45 UKNA, AIR 20/1166, "Report by Group Captain R.A. McMurtrie, D.S.O., D.F.C., Air Ministry, on Anti-U-boat Visit to the Indian Ocean November-December, 1943," 24 December 1943. Arthur Banks, Wings of the Dawning: The Battle for the Indian Ocean, 1939-1945 (Malvern Wells, Worcestshire: Images Publishing, 1996).

46 Lawrence Paterson, Hitler's Grey Wolves: U-Boats in the Indian Ocean (London: Greenhill, 2004). Michael Wilson, A Submariner's War: The Indian Ocean 1939-45 (Stroud: Spellmount, 2008). Hans-Joachim Krug, Yōichi Hirama, Berthold J. Sander-Nagashima, and Axel Niestlé, Reluctant Allies: German-Japanese Naval Relations in World War II (Annapolis: Naval Institute Press, 2001), 58-67.

47 UKNA, ADM 1/17006, Memorandum "Protection of Shipping in the Indian Ocean," 7 April 1944.

48 UKNA, ADM 1/1787, "Report on the A/S Organisation in South Africa," 16 April 1945.

49 Ashley Jackson, The British Empire and the Second World War (London: Hambledon Continuum, 2006). H.P. Willmott, Grave of a Dozen Schemes: British Naval Planning and the War against Japan, 1943-1945 (Annapolis: Naval Institute Press, 1996). Nicholas Evan Sarantakes, Allies Against the Rising Sun: The United States, the British Nations, and the Defeat of Imperial Japan (Lawrence: University Press of Kansas, 2009).

50 D.J. Hastings, The Royal Indian Navy, 1612-1950 (Jefferson, NC: McFarland, 1988), 104-12.

51 Major-General S. Woodburn Kirby, The War Against Japan vol. II (London: HMSO, 1958), 
minesweeping and escort duties for the predominantly British naval covering force. The battleship Ramillies, tasked from the eastern fleet, was damaged by a Japanese midget submarine in the harbour and was sailed to South Africa for repair. Despite numerous plans for amphibious operations (including seizure of the Andaman islands as an advance naval base) after the arrival of Admiral Louis Mountbatten as supreme commander in Southeast Asia, preparations were not ready and sufficient landing craft secured until 1945. Australian destroyers and a Royal Indian Navy landing craft wing supported Lieutenant-General Philip Christison's $15^{\text {th }}$ Indian Corps advance along the Arakan coast by landing at Akyab and with sea assaults on the Myebon peninsula and Ramree island. ${ }^{52}$ Sometimes misidentified as a campaign, this offensive effort was actually a supporting operation to General William Slim's 14 ${ }^{\text {th }}$ Army aimed at opening up ports for logistical supply of land operations against the Japanese in the hills and plains for a general advance to Rangoon. Burma's major port was captured in May 1945, which included a large-scale amphibious landing under the code-name 'Dracula'. Though the Royal Indian Navy landing craft wing was withdrawn for re-equipping, South African, Indian and Australian ships were busy in various tasks before and after Japan's final surrender. ${ }^{53}$ Great Britain and its main collaborators in imperial defence emerged as victors from the world war.

\section{Transition to Discrete Commonwealth Navies}

If the wartime experience instilled some measure of independence, autonomy, and sense of pride within the respective naval forces of Australia, India, and South Africa, the attainment of truly national navies in relation to the domineering Royal Navy came much later through a gradual process of disengagement. Post-war, the British Treasury and Admiralty quickly moved to close down redundant shore establishments abroad and liquidate surplus holdings, in a bid to limit expenditures until the export trade recovered. The financial position of Great Britain - teetering on national bankruptcy - was very dire and only saved by a big American loan. India possessed a large sterling surplus accumulated from the war years. ${ }^{54}$ Wartime facilities built by the Royal Navy in Australia, India and South Africa were sold and transferred; the governments involved naturally sought the best bargains in negotiations given the circumstances. The inflated

134-5. "The Capture of Diego Suarez (Operation Ironclad)," Supplement to the London Gazette, 2 March 1948.

52 UKNA, WO 203/3469, Report Lieutenant-Commander G.T. Torrens "R.I.N. Landing Craft," 24 February 1945. D.J.E. Collins, The Royal Indian Navy 1939-45 (Agra: Orient Longmans, 1964), 269-312. UKNA, CAB 106/74, “Account - Operations of 15 Indian Corps in the Third Arakan Campaign 1944-45 by Lieutenant-General Sir Philip Christison," 1947. University of Southampton Hartley Library Special Collections, Admiral Louis Mountbatten papers, series C file C102, Letter, Admiral Louis Mountbatten to Vice Admiral J.H. Godfrey, 26 January 1945.

53 UKNA, ADM 1/18426, Message CinC South Atlantic to Admiralty, 29 2136B August 1945.

54 UKNA, ADM 1/20339, Brief "Indian Sterling Balances: Defence Expenditure Arguments for Reduction," 24 January 1947. D. George Boyce, Decolonisation and the British Empire, 1775-1997 (New York: St. Martin's Press, 1999), 115. 
wartime navies struggled with their own problems of demobilization, closing down excess establishments, and paying-off war emergency ships. Delays and grievances caused a major mutiny in the Royal Indian Navy - involving more than 10,000 Indian sailors - during February 1946 that spread to the majority of shore establishments and ships. Investigations afterwards revealed deep resentment toward British officers and the structural racism implicit in the service. ${ }^{55}$ Other ranks in Australia showed similar sentiments toward British-trained naval officers aping imperial manners and forms, though not to the point of open mutiny. Most South Africans, separated by language and background, certainly were chauvinistic toward national self-determination. The South African Naval Forces was among the first to replace the White Ensign with a national flag. In each of the three (soon to be four with the inclusion of Pakistan) post-war navies, British leadership was still persistent and for the most part assumed.

Given the assumed imperial defence importance of the Indian Ocean, the British continued to exercise direct influence into the policy, organisation, and day-to-day running of navies in Australia, the Indian sub-continent, and South Africa. A definite ranking was felt to exist, and the smaller navies, it was argued, needed different periods of time to mature up to the exacting standards of the Royal Navy. Since the British Pacific Fleet had been based on Australia at the end of the war, ties were renewed and strengthened. Admiral Louis Hamilton, another British flag officer appointed in June 1945 taking over from Admiral Guy Royle, was Australia's first navy member and chief of the naval staff until the Australian Rear-Admiral John Collins assumed the post in 1948. The pre-retirement job was not Hamilton's first choice, but he energetically pushed future plans for the Royal Australian Navy in terms of ships and capability. Some priority was given to maintenance of sea lines of communication in the Indian Ocean to the rest of the Commonwealth and local defence. In Delhi, Vice-Admiral Geoffrey Miles replaced Admiral Godfrey to deal with the aftermath of the naval mutiny and restore loyalty in the Royal Indian Navy. ${ }^{56}$ The new British viceroy Lord Mountbatten advanced the timetable for withdrawal from India and accepted creation of a new Muslim state Pakistan through partition. Miles oversaw the division of naval assets between the two states, on roughly a two-to-one basis. ${ }^{57}$ India and Pakistan, the latter geographically separated into two parts, retained shore establishments within their respective borders and naval personnel were allowed to choose which navy they wanted to serve. Tensions over

55 BL/India Office, L/MIL/17/9/379, "Report of the R.I.N. Commission of Enquiry, 1946." William Richardson, "The Mutiny of the Royal Indian Navy at Bombay in February 1946," The Mariner's Mirror 79 (1993), 196. Dipak Kumar Das, Revisiting Talwar: A Study in the Royal Indian Navy Uprising of February 1946 (Delhi: Ajanta, 1993). Chris Madsen, "The Royal Indian Navy Mutiny, 1946," in Christopher M. Bell and Bruce A. Elleman, Naval Mutinies of the Twentieth Century: An International Perspective (London: Frank Cass, 2003), 212-31.

56 UKNA, ADM 1/21104, Report Vice Admiral Geoffrey Miles to Secretary Admiralty, 14 January 1948.

57 UKNA, ADM 1/21163, Special Military Branch Acquaint, 16 July 1947. Commander E.C. Streatfield-James, In the Wake: The Birth of the Indian and Pakistani Navies (Edinburgh: Charles Skilton, 1983), 219. V.A.K., "The Indian Navy," in Naval Review 4 (1953), 386. 
the disputed region of Kashmir soon complicated planned sharing agreements (the only naval dockyard in the western ocean was in Bombay), Field Marshal Claude Auchinleck, commander-in-chief in India, predicting it would take at least a decade for the split navies to recover from organizational turmoil. ${ }^{58}$ Commodore James Jefford, a British officer, took command of the smaller Royal Pakistan Navy. A commodore was also director of the South African Naval Forces, numbering fewer than 900 personnel by 1946 as part of the regular armed forces. ${ }^{59}$ The South African government asked the Admiralty for a suitable British officer of the same rank as a replacement in 1948. Prime Minister Field Marshal Jan Smuts, who exercised almost absolute control over South Africa's defence policy during his tenure, fell squarely on the side of local defence instead of the sea control navy advocated by the British. After 1948, the country turned inward with official promulgation of apartheid racial segregation and acted more and more like a neutral in external relations. India declared itself a republic in 1949, but chose to stay in the Commonwealth fold. ${ }^{60}$ The senior British naval officers and the navies were inexorably affected by the momentous changes taking place in the world, the region, and the countries themselves.

What role should the Commonwealth play in the Indian Ocean and what type of naval forces were required represented central questions. The Admiralty and many British naval thinkers held to the belief that the surest policy for defence was naval cooperation and common effort. Secure sea lines of communication remained vitally important. The pressing need was for similarly-equipped naval forces trained to comparable standards to perform escort functions. ${ }^{61}$ To this end, the British offered suitable used warships as well as new ones building. The Australians, the most experienced with big ships, appeared ready for light fleet carriers and additional cruisers. ${ }^{62}$ The stumbling block was price and politics. A home-grown shipbuilding industry lobbied hard to have any new warships designed and built in Australia, as the pace of technology relentlessly marched on with every delay. The gracefully maturing fleet made do with the ships on hand and took delivery of the first carrier Sydney (III), late of the Royal Navy. India acquired a cruiser, the Achilles re-christened Delhi, and a new British flag officer, Vice-Admiral William Parry (formerly captain of Achilles at the Battle of River Plate) badgered the Admiralty for assistance in developing a naval air arm

58 BL, Mountbatten Viceroy papers, Reel 15538 file 6A, "Remarks by H.E. the Commander-inChief." NMM, Admiral Geoffrey John Audley Miles papers, MLS/10/1, Letter Vice-Admiral Geoffrey Miles to Admiral John Cunningham, 25 August 1947. Anita Inder Singh, "Imperial Defence and the Transfer of Power in India, 1946-1947," in International History Review 4 (1982), 580.

59 UKNA, ADM 1/19434, Memorandum "The South African Naval Forces," 4 December 1945.

60 Hector Mackenzie, "An Old Dominion and the New Commonwealth: Canadian Policy on the Question of India's Membership, 1947-49," in Journal of Imperial and Commonwealth History 27 (1999), 96.

61 Lieutenant-Commander P.K. Kemp, "Commonwealth Co-operation in the Services," in Brassey's Annual (1950), 75-8.

62 UKNA, ADM 1/19051, Telegram Dominions Office to Australia Acting Prime Minister, 5 May 1945. 
with a light fleet carrier. Parry wrote Mountbatten: "Most of the Admiralty is very helpful - but for obvious reasons they can't do as much as we would like, particularly on the air side." ${ }^{\prime 3}$ In fact, the Admiralty had its doubts that the Indians could run so fast having just gained one cruiser, and Jawaharlal Nehru's government at most was ambivalent. Nehru did not become a convert to sea power until he and his family cruised on Delhi during an official state visit to Indonesia. ${ }^{64}$ Interest in British-sourced destroyers and frigates owed as much to the perceived enemy Pakistan as any work with the Royal Navy in the Indian Ocean. In 1949, the Admiralty transferred two former British destroyers to Pakistan for the sake of being fair. ${ }^{65}$ Pakistan actually wished submarines and land-based maritime strike aircraft to impose sea denial should India decide to attack and blockade. South Africa, which had its own differences with India over race policies, operated the three late-war frigates and took over two Algerine-class fleet minesweepers and a corvette in 1947. Local seaward defence and limited escort between South African ports were the anticipated tasks for these ships. For its part, the Admiralty tried to sell the idea that a balanced fleet based around light fleet carriers and cruisers, on the Australian model, was a good way to go. ${ }^{66}$ The reasons why the respective Commonwealth countries sought increased naval strength and specific capability quite often varied from British motivations for transferring warships in the first place, namely to promote greater naval cooperation and imperial defence.

The onset of the Cold War altered the entire strategic picture in the Indian Ocean and seemingly gave new rationale for Commonwealth participation in collective defence. The Soviet Union, which exploded its own atomic bomb in 1949, became the main enemy. Although predominantly a land-based power with a large conventional army, the Soviet Union gave increasing attention to strategic air (the long-range TU-4 essentially copied the B-29) and sea forces - surface and underwater. Estimates of Soviet naval strength included wartime and post-war construction in warships and submarines, the latter numbering a hundred or more. ${ }^{67}$ The nearest Soviet submarines were based at the

63 Southampton, Admiral Louis Mountbatten, series F file 5 folder 2, Letter, Vice-Admiral W.E. Parry to Rear-Admiral Louis Mountbatten, 30 October 1949. IWM, Admiral William Edward Parry papers, 71/19/8, "India and the Royal Indian Navy: Report by Vice Admiral W.E. Parry, C.B., after his first year as Commander-in-Chief, Royal Indian Navy," 15 August 1949.

64 IWM, Parry papers, 71/19/10, Letter, Parry to wife, 6 May 1950. Nehru became very fond of these naval cruises both for their symbolic and social value as "a new chapter in my voyage of discovery of India." Southampton, Mountbatten papers, series H file 177, clipping "Indian Navy is an Example in Disciplined Work: Prime Minister Returns from Cruise," The Hindustan Times (October 7, 1954).

65 UKNA, ADM 1/21487, Staff Minute Head of Military Branch, 19 August 1949.

66 UKNA, ADM 1/18481, Aide Memoire "Future of the South African Naval Forces," 1 February 1946.

67 Typhon, "The Strength of the Soviet Fleet," Naval Review 42 (1954), 190. The number of long-range submarines was fewer in the Pacific than other parts of the Soviet Union facing the western powers. Captain Donald Macintyre, "The Soviet Submarine Fleet," in Commander M.G. Saunders (ed.), The Soviet Navy (London: Weidenfeld and Nicolson, 
Pacific naval base at Vladivostok, and with resupply might have been able to reach the Indian Ocean. More menacingly, military planners feared that the Soviets coveted the Middle East to seize vital oil reserves and establish naval bases and airfields with access to the Indian Ocean.

British defensive plans looked to Australia, India and South Africa to send reinforcements, though the exact level of commitment and number of forces always remained unsettled. Pakistan tied any involvement in Middle East defence to the transfer of arms and munitions. ${ }^{68}$ Naval forces from the Commonwealth countries joined warships of the East Indies fleet and each other in sea exercises to practice antisubmarine warfare and protection of sea lines of communication. Having warships from Pakistan and South Africa work alongside those from India posed certain practical and political problems at times. ${ }^{69}$ The British generally encouraged cooperation and made special arrangements where necessary. In 1950, the names 'Indian Navy' and 'South African Navy' were adopted; Pakistan retained the prefix 'Royal' until 1956. The commander-in-chief East Indies argued for a separate war command in the Indian Ocean distinct from the land battle in the Middle East since "it would be essential that all these navies be co-ordinated by a superior operational authority in the area." ${ }^{70}$ In principle, he advocated the same organizational structure of the last war that maximized Commonwealth naval involvement under British superintendence.

The substantial commitment to naval operations in Korean waters necessarily stretched the Royal Navy's ability to put enough British ships in the Indian Ocean; prospective war in Europe or the Middle East meant even fewer ships. The participation of Commonwealth navies, therefore, was instrumental in any British plans for protection of trade and sea lines of communication in the Indian Ocean. ${ }^{71}$ The British came to rely on the maturing national navies, at a time when British tutelage was becoming progressively less important. Predisposed toward increased independence, individual members of the Commonwealth decided their own defence needs and alliances. The usefulness of imperial defence was passing quickly.

\section{Imperial Defence Recast East of Suez}

It is really quite remarkable how long British officials and the Royal Navy trusted that Great Britain could stay a world power with direct interests and influence in the Indian Ocean. The key deficiencies and challenges were certainly known and

1958), 172-3. Jürgen Rohwer and Mikhail S. Monakov, Stalin's Ocean-Going Fleet: Soviet Naval Strategy and Shipbuilding Programmes, 1935-1953 (London: Frank Cass, 2001), 205.

68

69

70

71 Brigadier C.N. Barclay, "Commonwealth Co-operation in Defence," Brassey's Annual (1951), 118-9. 
debated. ${ }^{72}$ The Commonwealth, in part legacy of a declining empire, was wholly indefensible as an entity without assistance from other leading powers. Great Britain was a member of important defence arrangements outside the Commonwealth, such as NATO, backed by the US nuclear deterrent. From the 1950s onwards, political and cultural aspects of the Commonwealth gained in prominence to economic and military justifications. Continued membership in the Commonwealth was an issue for some countries, while those who remained did so on their own terms. Commonwealth defence was not imperial defence because the premises were sufficiently different. The British were no longer supreme. Loose affiliation and solidarity among the navies concerned was aspired to, but not necessarily achieved. Australian self-sufficiency, tense relations between India and Pakistan, and isolationist tendencies in South Africa were major obstacles. The Admiralty became little more than a purveyor of ships and arms to countries all too ready to go elsewhere to meet their specific naval requirements.

The trends in Australia were already clearly evident. The Australian government drew back from military commitments in the Middle East in favour of the Pacific and south-east Asia. The Korean War, to which the Royal Australian Navy sent ships to augment Commonwealth and American naval forces, was a catalyst, but the choice represented reversion back to the earlier defence posture of forward defence in a dangerous neighbourhood. During a visit to Australia in October 1953, Field-Marshal Sir John Harding, chief of the imperial general staff, emphasized the importance in global war of Malaya and Australian leadership in ANZAM, a more or less moribund defence grouping that cut across the Indian Ocean. ${ }^{73}$ The United States was the dominant sea power in the Asia-Pacific region and this fact inevitably drew the Australian armed forces into closer contact and formal arrangements, much more so than the staid relationship with Great Britain and Commonwealth countries in the Indian Ocean. As part of its membership in the South East Asia Treaty Organization (SEATO), Australia made the counter-insurgency in Malaya a centre-point and devoted naval forces to a Far East strategic reserve. ${ }^{74}$ New destroyers and frigates, built in Australia to British design, gradually entered the fleet as capable, modern escort and air defence ships. After an extended period of construction and modification, the British finally delivered a second aircraft carrier to the Royal Australian Navy, commissioned Melbourne in 1955. Though the Admiralty had always encouraged a balanced fleet and interest in naval aviation among the Australians, the costs of carriers and their air complements taxed the government and almost sank the navy financially. The Sydney was used as a training ship and put into reserve in 1958. Relatively few ships, including the aircraft carriers, served any length of time in the Indian Ocean prior to 1960. Afterwards, the Australian navy

72 Admiral Sir Gerald Dickens, "The Commonwealth and Sea Power," Brassey's Annual (1957), 23-4.

73 UKNA, DO 35/6046, "Note of a Meeting in the Cabinet Room Canberra at 10.30 a.m. on the 16th October, 1953."

74 David Stevens, “The British Naval Role East of Suez: An Australian Perspective," in Greg Kennedy (ed.), British Naval Strategy East of Suez 1900-2000 (London and New York: Frank Cass, 2005), 232-3. 
gained more British auxiliary ships, established a submarine service with British help, and for the first time bought American-type destroyers. None of these acquisitions were justified in terms of imperial defence.

British policy toward India and Pakistan, meanwhile, was inseparable and carefully balanced. In the spirit of Commonwealth solidarity, the official line was that no gifts of warships and arms would be supplied for offensive purposes against another member, though in practice, the British were quite obliging to sell or loan if either party paid cash and ships were available on the reserve list. ${ }^{75}$ Three frigates were promised to India (almost not accepted because they were in such poor condition), and Pakistan obtained a fleet destroyer it had long desired on four year loan in return. Rear-Admiral Siddiq Choudri, chief of the naval staff replacing Jefford, had "grandiose ideas in the way of Aircraft Carriers, Cruisers and Submarines" according to Pakistan's defence minister General Iskandar Mirza, but talks at the Admiralty agreed "that these were more than Pakistan could afford... in the Naval role, Pakistan's requirement is to meet her own needs in full co-operation with the remaining Naval and Air Forces of the Commonwealth." ${ }^{76}$ When Pakistan signed a military aid and mutual assistance agreement with the United States in 1954, the British agreed to transfer four destroyers and a light cruiser paid out of American funds. Such a move had the potential to alarm the Indians because Pakistan's naval strength and capability stood to increase substantially. Thus, the Admiralty duly approved construction of six frigates and two minesweepers along with sale of a second refitted cruiser "in keeping with the part that it is hoped India might eventually take in Commonwealth defence in the event of war." 77 Both India and Pakistan probably harboured other ways in which the warships would be used in war, namely between themselves and not an international one involving the Commonwealth. Negotiations for a light fleet carrier started in 1955 and Nehru accepted purchase of the former Hercules two years later if payments could be extended until its completion in $1961 .^{78}$ The Indians were soon back in London asking for destroyers, at least comparable to those in Pakistan's hands. The Pakistan navy showed marginal interest in frigates and again sought submarines for "training" purposes going so far as to explore purchase in Sweden if the British said no. The Indians, with delivery of Britishtype anti-submarine warfare (ASW) frigates, also had claim on the training value of submarines. The leadership of the Indian navy passed from British Admiral Stephen

75 UKNA, PREM 11/957, Memorandum "Loan of Ships to India and Pakistan," 24 March 1953.

76 UK, DEFE 13/264, Memorandum First Sea Lord to Minister of Defence, 12 March 1954. Choudri wrote to Mountbatten: "We need capable and efficient R.N. officers to help in training the Pakistani officers. We have not been lucky in all cases in the past and any help which you may be able to give us in this respect will be greatly appreciated." Southampton, Mountbatten papers, series H file 144, Letter, Commodore H.M.S. Choudri to Admiral Louis Mountbatten, 23 October 1952.

77 UKNA, PREM 11/2291, Memorandum “Indian Naval Replacement Programme," 1955.

78 UKNA, PREM 11/1505, Letter Jawaharlal Nehru to Anthony Eden, 2 July 1956. See also PREM 11/957, Memorandum “Aircraft Carrier for the Indian Navy,” 26 July 1955. 
Carlill to a senior Indian officer, Vice-Admiral Ram Dass Katari, in April $1958 .^{79}$ India, officially a non-aligned country, entertained offers of military assistance from both the United States and the Soviet Union. Admiral Choudri ran afoul of Pakistan's president General Mohammed Ayub Khan for cost overruns associated with ambitious naval expansion and he resigned early in 1959. ${ }^{80}$ The cruiser Babur, the main object of the dispute, was reduced to a stationary training vessel and slated for scrapping if Ayub Khan had his say. By 1960, India and Pakistan had invested heavily in the build-up of naval forces, probably more than either country could afford. The Admiralty, on the pretence of imperial and Commonwealth defence, facilitated a mini arms race in the region by transferring warships to both sides. The contest may not have been of British making (arguably partition was), but India and Pakistan were better prepared militarily for coming conflict five years hence than if they had been left to building the warships themselves during this tense period.

Divergence between British interest in imperial defence and national motivation for naval development was similarly shown in South Africa. South Africa's sentiments lay with Europe, and it longed to be part of the western alliance in the early Cold War, as an affiliate with NATO or a like structure in Africa. ${ }^{81}$ The British connection at least served this purpose after 1948 when nationalist Afrikaner policies made the country a pariah in the eyes of many other western countries. The Admiralty recommended that the South African navy take over a larger Weapon-class or Battle-class destroyer of late-war design, or better yet two smaller ' $W$ '-class destroyers. These warships, kept in reserve, were slightly used and offered sea platforms with good handling. Transfer of British-type ships would also increase the likelihood that the South Africans might buy bigger, more capable British ships at a later date. A destroyer in reserve at Simon's Town, the Wessex, was sold to South Africa in March 1950 and renamed Jan van Riebeeck. The addition of such ships strained available personnel since the South African navy consisted of 132 officers and 1,499 other ranks, the smallest of the services in the Union Defence Forces. In 1952, the Admiralty offered the Whelp, another 'W'-class destroyer kept in category A reserve at Simon's Town, "to assist them in the protection of convoys round the Cape and to further expansion of the South African Navy." ${ }^{82}$ In other words, British encouragement was firmly based in imperial defence roles and a traditional view of Commonwealth navies. Once refit work was completed at South African expense, this second destroyer entered service in February 1953 as Simon van der Stel.

The South Africa navy's main base was at Durban facing the Indian Ocean,

79 Admiral R.D. Katari, A Sailor Remembers (New Delhi: Vikas Publishing House PVT, 1982), 78.

80 James Goldrick, No Easy Answers: The Development of the Navies of India, Pakistan, Bangladesh and Sri Lanka 1945-1996 (New Delhi: Lancer, 1997), 57-8. His successor, Vice-Admiral Afzal Rahman Khan, served as head of the Pakistan navy until 1966 and then in Ayub Khan's government as defence minister.

81 Christopher Coker, "South Africa and the Western Alliance, 1949-81: A History of Illusions," in Journal of the Royal United Services Institute for Defence Studies 127/2 (1982), 34-5. 
though negotiations began for transfer of the imperial naval base and dockyard at Simon's Town to South African ownership. On 30 June 1955, representatives of South Africa and Great Britain signed the so-called Simonstown Agreement that put the transfer into effect by April 1957, granted the Royal Navy continued use of the naval base, and led the South African government to order three Type $12 \mathrm{ASW}$ frigates, ten Ton-class coastal minesweepers, and five Ford-class seaward defence boats from British sources. The deal was an attempt to safeguard British strategic interests in the Indian Ocean and tie South Africa to British supply of arms. ${ }^{83}$ In the bargain, the South African navy received the foundation for a small, modern naval force by 1960. A year later, South Africa became a republic and left the Commonwealth. The Simonstown agreement caused festering resentment within South Africa, though it allowed the Royal Navy and South Africa Navy to participate in joint exercises in the Indian Ocean well into the 1970s. In these decades, the South African navy was an ageing (some observers used the word "rusting") coastal and seaward defence force. International pressure to end apartheid in South Africa ultimately severed formal military relations until the African National Congress assumed power in 1994 and created the South African National Defence Force, of which the renewed blue-water South Africa Navy forms a part.

In the end, reduced permanent British naval presence in the Indian Ocean signalled the demise of imperial defence. The East Indies station was abolished as an independent maritime command in September $1958 .{ }^{84}$ Tenure at the Trincomalee naval base was neither welcome nor viable due to nationalist sentiment in Ceylon, and the Royal Navy simply did not have the personnel, ships and money to remain distributed globally outside Europe to the extent it had been. Kilindini, the other main Royal Navy base in the Indian Ocean, was still available. In fact, it was the designated rally point for any surviving remnants of British fleets in the event of nuclear war. The wisdom of locating a petroleum refinery beside the naval base, notwithstanding the economic benefit to Kenya's government and Mombasa, was certainly problematic since a simple conventional attack sufficed to obliterate the entire area. ${ }^{85}$ The Soviets no doubt nucleartargeted most known naval bases anyways. As the British pulled back, the US Navy also showed interest in bases and supply for deployed forces in the Indian Ocean, including leases on British-held islands such as Diego Garcia. ${ }^{86}$ The arrival of the US superpower represented a major strategic shift in the Indian Ocean as Commonwealth navies found a

83 Peter James Henshaw, "The Transfer of Simonstown: Afrikaner Nationalism, South African Strategic Dependence, and British Global Power," in Journal of Imperial and Commonwealth History 20 (1992), 437.

84 UKNA, ADM 116/6281, Memorandum "Winding up of East Indies Station," 22 August 1958.

85 UKNA, ADM 1/24873, Letter "Mombasa Oil Refinery Scheme," 3 October 1953. David A. Percox, Britain, Kenya and the Cold War (London and New York: I.B. Tauris, 2004), 100.

86 UKNA, DEFE 7/1652, Memorandum "U.S. Navy Interest in Indian Ocean: Brief by Admiralty for Visit of Chief of Staff, Far East Station, to CINCPAC Fleet, Pearl Harbour [sic], August 1959." Diego Garcia had first been considered as a base in 1941. UKNA, ADM 1/26876, "Naval Fuelling Anchorages in the Indian Ocean and Far East," 19 July 1941. 
new partner to work with. In this maritime region, withdrawal East of Suez started long before British Prime Minister Harold Wilson's declared policy change in 1967.

\section{Conclusion}

Imperial defence was an alluring idea in the Indian Ocean as long as a significant British presence lasted. For the Royal Navy, the East Indies station was little more than a thoroughfare between the Mediterranean and Far East tying together the British interests of empire. In spite of the political and economic importance of India and other British territories in the Indian Ocean, actual British naval forces resident there were limited compared to other competing areas of demand. The Admiralty encouraged the development of navies in Australia, India, and South Africa in part to address this weakness, along the lines of its concept of common naval cooperation and integration. These countries formed a triangle that had potential for effective control of the whole vast ocean. British influence was strong in these small navies and they were offered Britishtype ships, training, and leadership. The dominions and India, however, held their own views about application of sea power in relation to land power, suitable naval forces, and the costs involved, frequently at odds with the British. They might have been pleased to get ships and assistance when wanted, but whether they wholeheartedly bought into imperial defence arguments is less certain. Actions and policy speak otherwise. Indeed, national navies emerged out of the wartime experience due to British weakness in the Indian Ocean when faced with the Japanese threat, new political realities in the post-war period, and the coming standoff with the Soviet Union in the Cold War. Though the British retained a latent belief in imperial defence and shared effort, the Commonwealth countries and their navies went off in various directions. Australia, India, Pakistan and South Africa, finding their own way in the world as independent nations, gave pretence to imperial and Commonwealth defence when it suited them, and found other arrangements when it did not. British agency in the affairs of these navies ceased by 1960, if not before, with the Royal Navy's general pull-back in the Indian Ocean and globally.

It is hard to say whether the association with imperial defence and British primacy actually helped or hindered the countries involved in achieving naval forces best suited to their individual needs and finances. A good case could have probably been made for coastal navies with some limited power projection and no more. Indeed, the region might just have been more peaceful and less inclined to military conflict between states. ${ }^{87}$ Australia, India, Pakistan and South Africa certainly had the navies they got because of persistent British interest - one might even venture meddling - in the Indian Ocean. In spite of having evolved in very different ways since, today's navies can all claim affinity as Commonwealth navies through a shared background and history tied to the bygone notion of imperial defence in the maritime sphere.

87 Mihir K. Roy, War in the Indian Ocean (New Delhi: Lancer, 1995). 